\title{
A Five-Year Review of Soft Tissue Tumors with Intermediate Malignant Potential and Soft Tissue Sarcomas in a Tertiary Hospital: University of the Philippines - Philippine General Hospital*
}

Joeanne Marie Salise and Jenny Maureen Atun

${ }^{1}$ Department of Laboratories, University of the Philippines-Philippine General Hospital

${ }^{2}$ Department of Pathology, College of Medicine, University of the Philippines, Manila

\section{ABSTRACT}

Objective. Describe the epidemiology of Soft Tissue Tumors with Intermediate Malignant Potential (STTI) and Soft Tissue Sarcomas (STS) diagnosed in Philippine General Hospital, Department of Laboratories, Section of Surgical Pathology, from years 2014 to 2018.

Methodology. We utilized a descriptive, retrospective, cross-sectional study design and involved all newlydiagnosed cases of STTI and STS that fit the specified set of inclusion and exclusion criteria.

Results. Out of 1896 cases of probable STTI and STS on initial screening, 680 cases (36\%) were included in the study. Of the 1216 excluded cases, 815 (43\%) needed ancillary diagnostic workup for definitive classification. Sarcoma, Not Otherwise Specified ( $n=149 ; 21.9 \% ; 95 \% \mathrm{Cl}[18.80,25.02])$ was the most common diagnosis, followed by gastrointestinal stromal tumor ( $\mathrm{n}=91 ; 13.4 \% ; 95 \% \mathrm{Cl}[10.82,15.94])$ and leiomyosarcoma $(\mathrm{n}=62 ; 9.1 \% ; 95 \% \mathrm{Cl}[6.95 \%, 11.28 \%])$. Median age was 47 years, with a slight female predominance $(\mathrm{n}=371$; $55 \% ; 0.83$ male to female ratio). The extremities $(n=244,36 \%)$ were the most frequent site.

Conclusion. The significant amount of cases excluded in the study may account for the differences of distribution. Despite the increased immunohistochemistry tests available, there is still an apparent inaccessibility to ancillary diagnostic methods that are necessary in the diagnosis of STTI and STS.

Key words: soft tissue neoplasms, sarcoma, Philippines

ISSN 2507-8364 (Online)

Printed in the Philippines.

Copyright $(2021$ by the PJP.

Received: 28 May 2021.

Accepted: 18 June 2021.

Published online first: 30 June 2021

https://doi.org/10.21141/PJP.2021.09

Corresponding author: Joeanne Marie M. Salise, MD

E-mail:jmsalise@up.edu.ph

*This research paper was presented in the $26^{\text {th }}$ Annual Residents' Research Forum of the University of the PhilippinesPhilippine General Hospital, Department of Laboratories, last March 4, 2021.

\section{INTRODUCTION}

Soft tissue is defined as nonepithelial extraskeletal tissue of the body, principally derived from the mesoderm, with some contribution from the neuroectoderm. It is represented by the voluntary and involuntary muscles, fat, fibrous tissue and vessels supporting these tissues. Components of the peripheral nervous system are included as well, since tumors from nerves present as soft tissue masses with similar differential diagnoses and therapeutic measures. It does not include the reticuloendothelial system, glia, and supporting tissue of various parenchymal organs. ${ }^{1,2}$

Tumors arising from soft tissues are mainly classified according to their line of differentiation or adult tissue they resemble. They are further divided into benign and malignant forms. Benign tumors resemble their normal tissue counterparts, have a limited capacity for autonomous growth, exhibit little tendency to invade and have a low rate of local recurrence following conservative therapy. Malignant tumors, or STS, in contrast, are locally aggressive, capable of invasive growth, recurrence, and distant metastasis, and require radical surgery to ensure total removal. Unfortunately, this dichotomous differentiation is not perfect as the term sarcoma does not correlate well with likelihood or rapidity of metastasis. Due to this, STS are sometimes qualified by a statement regarding degree of differentiation or the histologic grade. Tumors of intermediate or borderline malignancy 
are characterized by frequent recurrence but rare metastasizing potential. ${ }^{1,3,4}$

Benign soft tissue tumors outnumber malignant tumors by a factor of 50, according to Goldblum et al. STS are relatively rare compared to other neoplasms and reported incidences vary from less than 1 to $1.5 \%$ of all cancers, with an annual incidence of 50 per million population. The incidence and distribution of STS appear to be similar in different regions of the world. This is also noted by WHO wherein no significant geographical difference in sarcoma incidence was found. Despite this, it has been reported that a relationship exists between patient age, sex, tumor histologic type and tumor site. ${ }^{1,3}$

According to the SEER database, the incidence of STS varies with age. In children younger than 10 years of age, the annual incidence was $0.9 / 100,000$ children. It was found to be higher in adults over the age of 70 years, with an incidence of 18.2/100,000 adults. The WHO reports the median age at diagnosis to be at 65 years. ${ }^{2}$

In general, STS are found to be more common in males, but gender and age-related incidences vary among the histologic types. There is also no proven racial variation. ${ }^{1,2}$

STS can occur anywhere, but most arise from the large muscles of the extremities, the chest wall, the mediastinum, and the retroperitoneum. Seventy-five percent are located in the extremities, most commonly in the thigh. Ten percent each are found in the trunk wall and retroperitoneum. ${ }^{3,5}$

The diversity of soft tissue tumors is emphasized in the 2020 WHO Classification of Tumors of Soft Tissue, wherein they are listed according to their line of differentiation. Tumors are classified under undifferentiated/unclassified sarcomas if no line of differentiation is identified using presently available technology and is a diagnosis of exclusion. They account for $20 \%$ of all STS and occur in all ages with no observed sexual predilection. ${ }^{3}$

According to the SEER Cancer Statistics Review (2012-2016), sarcoma, not otherwise specified (22.3\%) was found to be the most common STS diagnosis reported. This is followed by liposarcoma (16.6\%), leiomyosarcoma (12.8\%), miscellaneous other sarcomas $(8.1 \%)$, fibrosarcoma $(7.9 \%)$, synovial sarcoma $(4.6 \%)$, dermatofibrosarcoma (4.3\%), malignant fibrous histiocytoma $(4.2 \%)$, hemangiosarcoma $(4.1 \%)$, and giant cell and extraskeletal bone sarcomas $(3.2 \%){ }^{2}$

A systematic review on STS in the Asia-Pacific Region was done by Ngan et al., in 2013. Thirty-five published articles were included, 29 of which were from Australia, Korea and Taiwan. No study from Indonesia, New Zealand and the Philippines met the inclusion criteria. Pleomorphic sarcoma and liposarcoma were found to be the most common histologic type reported (23/32 studies). The mean or median age of patients with STS was found to be 40 years or older (27/30 studies), while the minimum age was younger than 18 years (14/30 studies). They found most sarcomas to be located in the extremities, consistent with reported literature worldwide. ${ }^{6}$
In a study by Ngelangel and Wang on Cancer and the Philippine Cancer Control Program in 2002, STS were reported to be 4.2 per million among children aged 0-14 years old. Rhabdomyosarcoma and fibrosarcoma were the only specific entities cited with incidence rates of 2.3 and 0.8 per million, respectively. However, this study was limited to Rizal province and four cities in Metro Manila, namely, Quezon, Manila, Caloocan and Pasay. These incidence rates were based on data gathered in the said areas during the years 1983 to $1992 .^{7}$

\section{OBJECTIVES}

\section{General Objective}

- Describe the epidemiology of STTI and STS diagnosed in Philippine General Hospital (PGH), Department of Laboratories, Section of Surgical Pathology, from January 1, 2014 to December 31, 2018.

\section{Specific Objectives}

- Enumerate all cases of STTI and STS diagnosed in the hospital.

- Determine the distribution of STTI and STS diagnosed in the hospital, according to age, sex, tumor classification, tumor histologic type and tumor site.

- Compare the epidemiology of STTI and STS diagnosed in the hospital with published literature.

\section{METHODOLOGY}

\section{Study Design}

This is a descriptive, retrospective, cross-sectional study design.

\section{Study Population}

The study involved all cases of diagnosed STTI and STS, in accordance with the inclusion criteria below. It enumerated all cases that fulfilled the set criteria within the time period specified.

\section{Inclusion Criteria}

1. All newly-diagnosed inpatient and outpatient cases rendered with a definite diagnosis of STTI and STS (inclusive of soft tissue tumors with intermediate and malignant potential listed in the WHO Classification of Tumors of Soft Tissue, 2020) from January 1, 2014 to December 31, 2018, in the PGH, Department of Laboratories, Section of Surgical Pathology, confirmed using histomorphologic assessment, with or without ancillary immunohistochemistry and/or molecular testing.

\section{Exclusion Criteria}

1. Cases rendered with a definite diagnosis of a benign soft tissue tumor, as listed in the $\underline{W H O}$ Classification of Tumors of Soft Tissue, 2020.

2. Cases of soft tissue tumors whose biologic behavior cannot be classified as benign, intermediate, or malignant due to limited information in the final diagnosis.

3. Cases with incomplete data on age, sex, tumor site and histologic diagnosis.

4. Cases of recurrent or persistent STTI and STS that are status post treatment (e.g., chemotherapy, radiotherapy, etc.). 


\section{Data Collection and Processing}

Data were obtained from surgical pathology reports of all patients that have been diagnosed with STTI and STS from January 1, 2014 to December 31, 2018. Only data on the patients' age, sex, tumor site and histologic diagnoses were obtained from the surgical pathology reports.

A research assistant was hired to assist in the data collection, with permission requested from the Chair of the Department of Laboratories, as well as from the Head and Supervisor of the Section of Surgical Pathology. The principal investigator trained the research assistant regarding the data collection procedure, with emphasis on patient privacy and confidentiality.

Retrieval of anonymized data from surgical pathology reports into data collection forms (Appendix A) were facilitated by an authorized laboratory technologist who subscribed, sworn and signed the Confidentiality and Non-Disclosure Undertaking of the hospital. The data collection forms were then given to the research assistant for encoding into the master spreadsheet (Appendix B).

Data collection was done within office hours and within the Section of Surgical Pathology, to ensure that records remain in the section and minimize risk of breach of patient confidentiality. A brief diagrammatic workflow is provided in Appendix C.

\section{Intervention}

Not applicable.

\section{Outcome}

Epidemiology of STTI and STS in PGH.

\section{Analysis}

Data were collected and tabulated using Microsoft Excel 2019. Microsoft Excel 2019 and Stata version 16 were used to analyze the data which were entered according to a coding manual (Appendix D).

Descriptive statistics were computed for all demographic variables available using Microsoft Excel 2019 and Stata software. Summary statistics (i.e., mean, range, median) were used for quantitative variables like age while for categorical data, data were summarized using frequencies and proportions. Tables and graphs were utilized to display findings more clearly. Data processing and analysis were carried out using Microsoft Excel 2019 and Stata software.

\section{Ethical Considerations}

Prior to commencement of the study, an institutional ethical approval coursed through the PGH Expanded Hospital Research Office was sought. The study was conducted only upon approval from the University of the Philippines Manila Research Ethics Board (UPMREB).

The patient demographic and clinical information needed in the study were retrieved from the surgical pathology reports filed at the Department of Laboratories, Section of Surgical Pathology. Patients names were not obtained. There was no patient-investigator interaction and only surgical pathology records were accessed for review.

The principal investigator solely funded this research.

\section{Waiver of consent}

A waiver of consent was requested from UPMREB since there are no risks to participants and the method of data collection ensured that none of the participants were identifiable and anonymity was ensured (NEGHHR 2017 provision 16.2.3 and 17.1). The waiver did not adversely affect the rights and welfare of the participants (NEGHHR 2017 17.2) and the research was not practicably carried out without the waiver (NEGHHR 2017 17.3). A plan for data collection was discussed earlier in the protocol.

\section{RESULTS AND DISCUSSION}

A total of 680 cases diagnosed as STTI and STS were identified and included in the study after extensive review of all surgical pathology reports signed out at PGH, Department of Laboratories from January 1, 2014 to December 31, 2018. This comprised 36\% of the 1896 cases of probable STTI and STS gathered on initial screening (Figure 1). Steps were taken to ensure that each diagnosis belonged to only one patient. Cases of recurrent or persistent STTI and STS that underwent

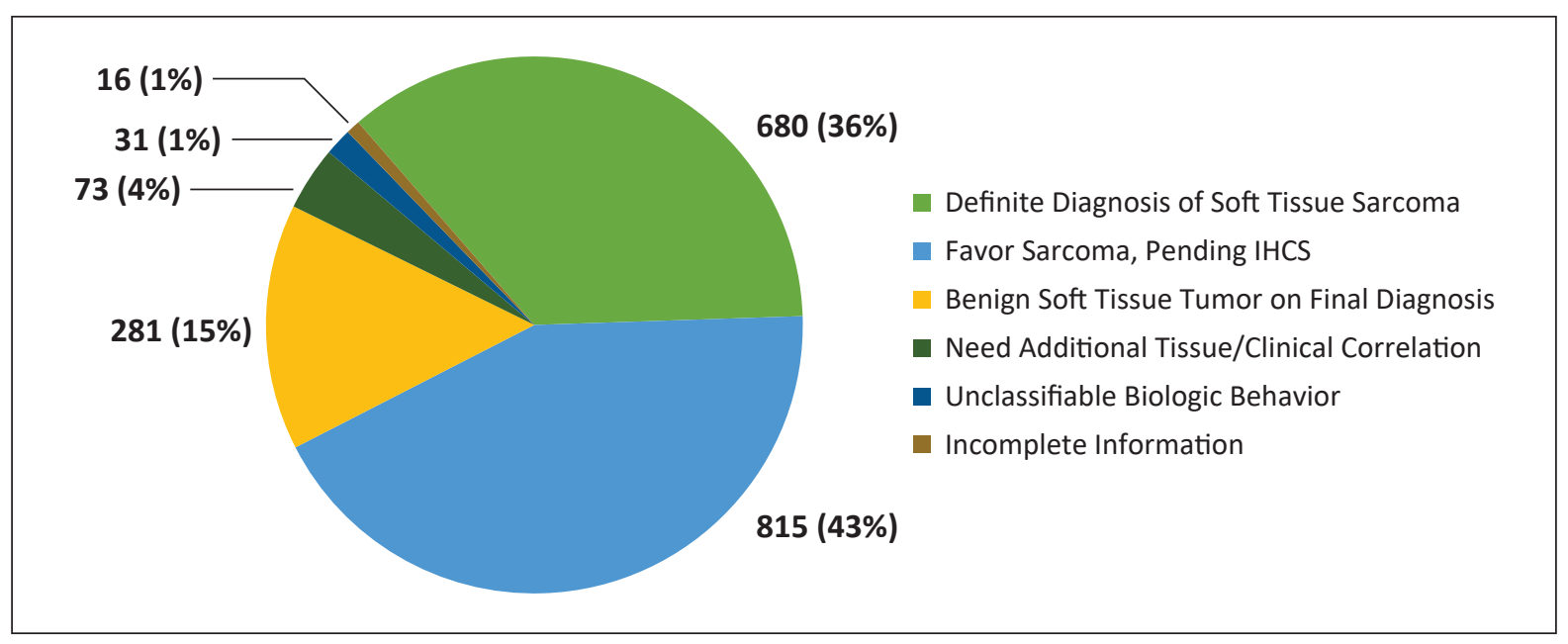

Figure 1. Distribution of cases of probable STTI and STS on initial screening. 
treatment (e.g., chemotherapy, radiotherapy, etc.) were counted as one, together with the initial diagnosis prior to treatment, so as to prevent duplication of counts.

A total of 1216 out of 1896 cases (64\%) of probable STTI and STS were excluded upon initial screening. Majority $(\mathrm{n}=815$ out of $1216,67 \%)$ of the inconclusive cases were either attributed to total lack of, or incomplete, immunohistochemical (IHC) workup (Table 1). This is a significant finding given the setting of a tertiary referral hospital, highlighting the need for improvement of availability and accessibility of necessary ancillary diagnostic tests, including, but not limited to immunohistochemistry methods and cytogenetic studies.

Figure 2 shows an increasing trend in the number of STTI and STS diagnosed in PGH from January 1, 2014 to December 31, 2018.

Figure 3 shows the age and sex distribution of STTI and STS in PGH from 2014-2018, stratified according to age. The 2020 WHO Classification of Tumors of Soft Tissue reports the general distribution of sarcomas to have a slight male predominance. Results of the study show that there is a slight, albeit insignificant, female predominance $(\mathrm{n}=371 ; 55 \% ; 95 \%$ CI $[50.82,58.30] ; 0.83$ male to female ratio; $\mathrm{p}$ value $=0.9997)$, over males $(\mathrm{n}=309 ; 45 \%$; $95 \%$ CI $[41.70,49.18])$ in the sarcomas diagnosed in PGH.

As with other malignancies, sarcomas are increasingly common with older age, with a reported median age of 65 years ${ }^{8}$ Results showed that sarcomas were most common among the older adults, 45-64 years of age $(n=240,35 \%)$, however, with a much younger median age of 47 years. This finding is still consistent to the reported "mean or median age" of "40 years or older" ( $n=27$ studies) in the systematic review of STS in the Asia-Pacific Region by Ngan et al., in $2013 .^{6}$

The order of distribution of sarcomas according to age and tumor classification is shown in Figure 4. Sarcomas have been reported to have varied age-related incidences. Of special note is embryonal rhabdomyosarcoma, which is known to occur almost exclusively in children, and synovial sarcoma, which mostly occurs in young adults. Results of the study revealed that of the 11 cases of embryonal rhabdomyosarcoma NOS in the years 20142018 , ten of these were found to be in patients less than 18 years old (range $=3$ to 22 years old), with a median age of 10 years. Another 12 cases of sarcomas were

\begin{tabular}{|c|c|}
\hline Reason for exclusion & Number of cases (\%) \\
\hline $\begin{array}{l}\text { Cases favoring the diagnosis of STTI/STS, pending } \\
\text { recommended immunohistochemical studies to } \\
\text { exclude other tumors. }\end{array}$ & $815(67)$ \\
\hline $\begin{array}{l}\text { Cases rendered with a final diagnosis of a benign soft } \\
\text { tissue tumor. }\end{array}$ & $281(23)$ \\
\hline $\begin{array}{l}\text { Cases with STTI/STS in the differential diagnosis but } \\
\text { with recommendation for additional tissue biopsy, } \\
\text { excision, or clinical correlation for definite classification. }\end{array}$ & $73(6)$ \\
\hline $\begin{array}{l}\text { Cases of probable STTI/STS whose biologic behavior } \\
\text { cannot be classified as benign, intermediate, or } \\
\text { malignant due to limited information in the final } \\
\text { diagnosis. }\end{array}$ & $31(3)$ \\
\hline $\begin{array}{l}\text { Cases of probable STTI/STS with incomplete data on } \\
\text { age, sex, tumor site and histologic diagnosis. }\end{array}$ & $16(1)$ \\
\hline Total & 1216 \\
\hline
\end{tabular}

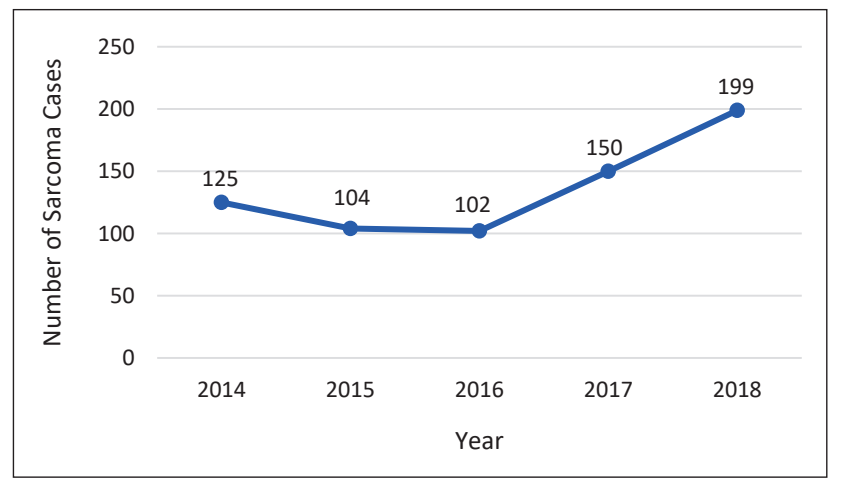

Figure 2. STTI and STS diagnosed in PGH from January 1, 2014 to December 31, 2018.

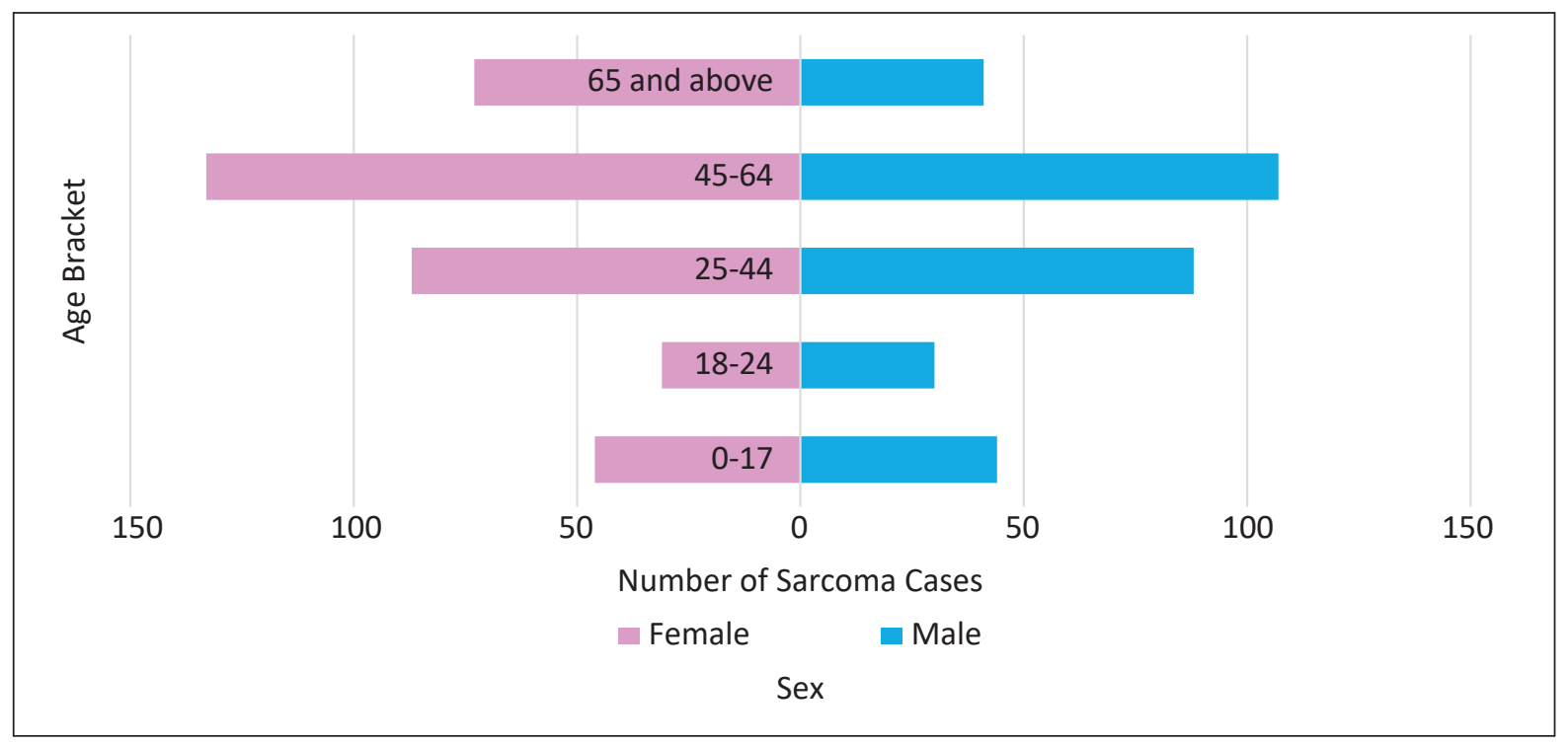

Figure 3. Age and sex distribution of STTI and STS diagnosed in PGH from January 1, 2014 to December 31, 2018. 


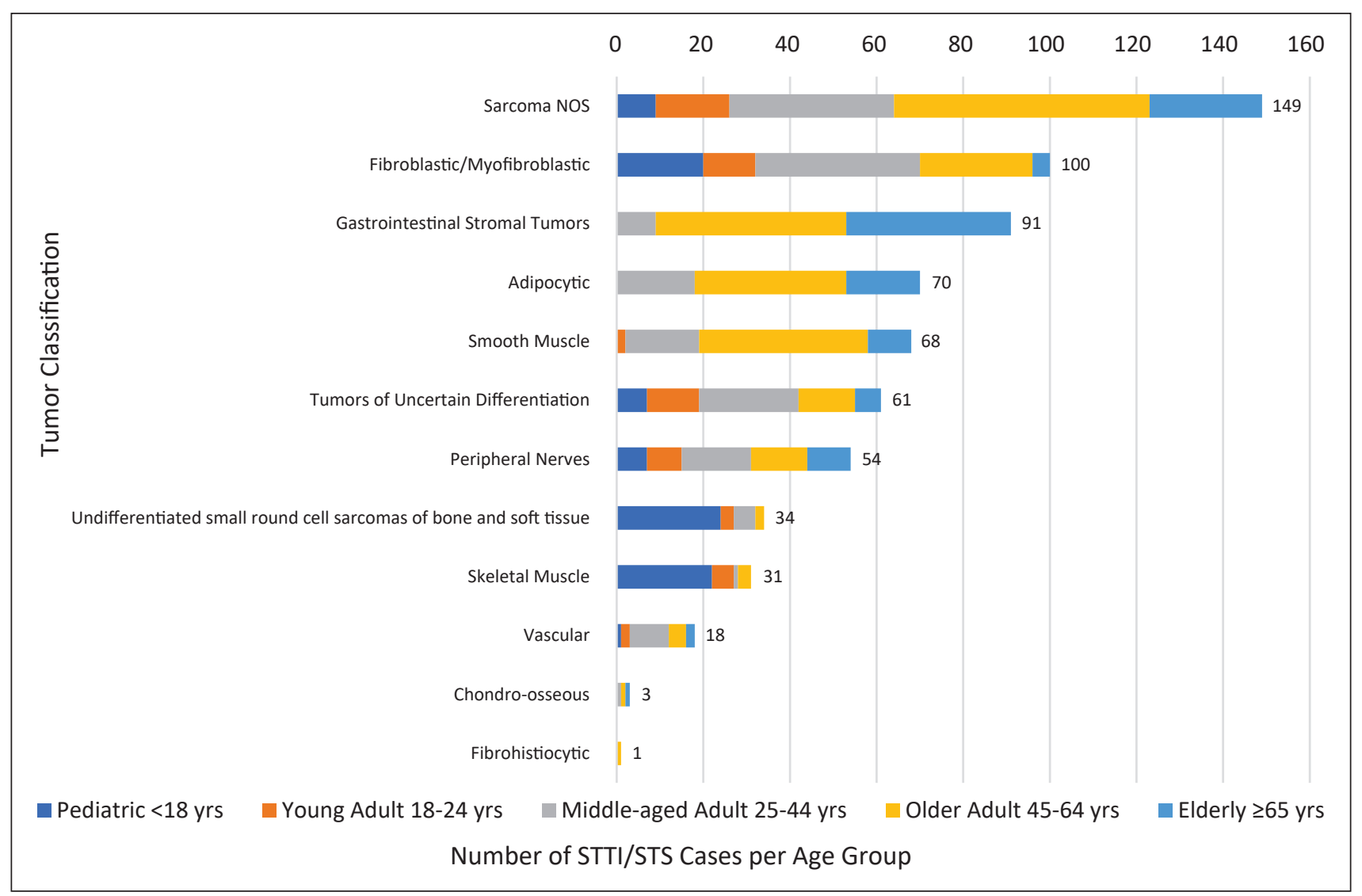

Figure 4. Distribution of STTI/STS diagnosed in PGH from January 1, 2014 to December 31, 2018 according to age and tumor classification.

diagnosed as "Rhabdomyosarcoma", without further subclassification (median age $=12.5$ ). Among these, six cases were below 18 years old. Based on the epidemiology of rhabdomyosarcomas in this age group, some of these may in fact be of embryonal subtype.

Among the sarcomas with definite tumor classification, fibroblastic/myofibroblastic tumors were the most common $(\mathrm{n}=100 ; 14.7 \% ; 95 \%$ CI $[12.04 \%, 17.37 \%])$. Majority of the cases were classified under Sarcoma, Not Otherwise Specified (Sarcoma NOS; $n=149 ; 21.9 \%, 95 \%$ CI $[18.80 \%$, $25.02 \%])$. This is an additional category, in addition to the diagnoses dictated by the 2020 WHO Classification of Soft Tissue Tumors, arbitrarily delegated in this study and adopted from the SEER database, for cases diagnosed as definite STTI and STS, pending more specific tumor classification. This fact remains to be a significant limiting factor in the diagnosis of STTI and STS and reiterates the need for more advanced techniques in the diagnosis of sarcomas received in our institution. . $^{2,8}$

The top ten most common STTI and STS histologic types enumerated in this study are listed in Table 2. The results of this study highlight both the similarities and differences between incidences of diagnosed STTI and STS in different populations. Both the SEER database and results of this study showed Sarcoma NOS $(p=0.8055)$, leiomyosarcoma $(p=0.0045)$, synovial sarcoma $(p=1.0000)$ and dermatofibrosarcoma $(p=0.01587)$ to be among the most commonly diagnosed sarcomas. Leiomyosarcoma and dermatofibroma were found to be significantly different in the two populations $(p<0.05)$. Following

\begin{tabular}{|c|c|c|c|}
\hline \multicolumn{2}{|l|}{ Results } & \multicolumn{2}{|c|}{ SEER, 2012-2016 } \\
\hline STTI/STS Histologic Type & $\begin{array}{c}\text { Number of } \\
\text { Cases (\%) }\end{array}$ & Histologic Type & $\begin{array}{c}\text { Percentage } \\
\text { (\%) }\end{array}$ \\
\hline Sarcoma, NOS & $149(21.9)$ & Sarcomas, NOS & 22.3 \\
\hline $\begin{array}{l}\text { Gastrointestinal } \\
\text { stromal tumor }\end{array}$ & $91(13.4)$ & Liposarcomas & 16.6 \\
\hline Leiomyosarcoma NOS & $62(9.1)$ & Leiomyosarcomas & 12.8 \\
\hline $\begin{array}{c}\text { Malignant peripheral } \\
\text { nerve sheath tumor NOS }\end{array}$ & $54(7.9)$ & $\begin{array}{l}\text { Miscellaneous } \\
\text { other sarcomas }\end{array}$ & 8.1 \\
\hline Ewing sarcoma & $32(4.7)$ & Fibrosarcomas & 7.9 \\
\hline Synovial sarcoma NOS & $31(4.6)$ & Synovial sarcomas & 4.6 \\
\hline Solitary fibrous tumor NOS & $25(3.7)$ & Dermatofibrosarcomas & 4.3 \\
\hline Myxoid liposarcoma & $22(3.2)$ & $\begin{array}{l}\text { Malignant fibrous } \\
\text { histiocytoma }\end{array}$ & 4.2 \\
\hline Fibromatosis & $22(3.2)$ & Hemangiosarcomas & 4.1 \\
\hline $\begin{array}{c}\text { Dermatofibrosarcoma } \\
\text { protuberans NOS }\end{array}$ & $20(2.4)$ & $\begin{array}{l}\text { Giant cell and extra- } \\
\text { skeletal bone sarcomas }\end{array}$ & 3.2 \\
\hline
\end{tabular}

Sarcoma NOS, gastrointestinal stromal tumor (GIST) is the most common diagnosed STTI/STS in our institution, which was not included in the SEER 2012-2016 ten most common sarcomas. Malignant peripheral nerve sheath tumor (MPNST), Ewing sarcoma, solitary fibrous tumor, myxoid liposarcoma, and fibromatosis were not among the most common in the SEER database. ${ }^{2}$

WHO cites undifferentiated pleomorphic sarcoma (UPS, previously malignant fibrous histiocytoma and listed as such in the 2012-2016 SEER data), liposarcoma, leiomyosarcoma, myxofibrosarcoma, synovial sarcoma, 
and MPNST to comprise approximately $65 \%$ of STS. ${ }^{8}$ In the exhaustive systematic review of STS in the AsiaPacific region by Ngan et al., pleomorphic sarcoma and liposarcoma were the predominant histologic types. ${ }^{6}$

Solitary fibrous tumor NOS and fibromatosis were among the top ten sarcomas reported in this study. Both tumors belong to the category of Intermediate Malignant Potential in the WHO Classification and were notably absent in the SEER 2012-2016 data, which only reported frankly malignant sarcomas.

Results showed that $36 \%(n=244)$ of the STTI and STS diagnosed in PGH were located in the extremities (Figure 5). This is followed by the trunk $(\mathrm{n}=128,18.8 \%)$ and head and neck $(n=126,18.5 \%)$ in close proximity to each other. The data is congruent with the WHO database which also showed the extremities to be the common site, although twice more often at $75 \%$. Ten percent each are found in the trunk wall and retroperitoneum. ${ }^{8}$ The extremities were also the most common site of STTI and STS in the systematic review by Ngan et al. ${ }^{6}$

Tables 3 and 4 in the succeeding pages show the overall distribution of sarcomas diagnosed in $\mathrm{PGH}$ in the years 2014-2018 according to tumor classification, age, sex and tumor site, respectively. There were four STTI/STS diagnoses that couldn't be classified under the current WHO Classification due to need for further subtyping, namely, "Fibromatosis," "Hemangioendothelioma," "Rhabdomyosarcoma" and "Rhabdomyosarcoma, EmbryonalAlveolar." Separate counts were done for these entries. No case of Malignant Glomus Tumor, under Pericytic/ Perivascular STS in the WHO tumor classification, has been diagnosed in the years 2014-2018.

The significant amount of cases excluded in the beginning of the study may account for the differences of distribution in the STTI and STS diagnosed in PGH. Unless these cases are pursued until a specific diagnosis is reached, the true incidence may never be known. Of course, even in the ideal setting, there will be tumors that remain elusive to classification, which may aptly be called true Sarcomas, not otherwise specified. In the United States SEER database for STS in the years 2002-2014, Sarcoma, NOS was the most common category at $14.8 \% .^{2,9}$ In the latest WHO Classification, these tumors that failed to show any identifiable line of differentiation after analysis using presently available technology are classified under Undifferentiated Sarcoma, which comprises approximately $20 \%$ of all STS. ${ }^{8}$

Despite the apparent unmet need in diagnostic ancillary testing, the increased number of diagnosed STTI and STS cases through the years 2014 to 2018 remains to be promising. This may simply be due to an increase in number of patients catered by PGH. However, this may also be reflective of the successful efforts of the Division of Surgical Pathology in acquiring and providing immunohistochemical stains necessary in the diagnosis of STTI and STS. There may have been an increase in the number of tumors, initially diagnosed as nonspecific "Spindle Cell Neoplasms," subjected to immunohistochemical studies, and subsequently rendered with the definitive diagnosis of STTI or STS.

In the recent years, the hospital has been able to increase the number of diagnostic tests which cater specifically to the diagnosis of sarcomas. However, there is still plenty of room for improvement of molecular and cytogenetic testing in the classification of sarcomas. Furthermore, as majority of the patients in PGH belong to the lower socioeconomic strata of the country, other factors such as the accessibility of these more costly diagnostic tests to the catered population of the hospital cannot be discounted.

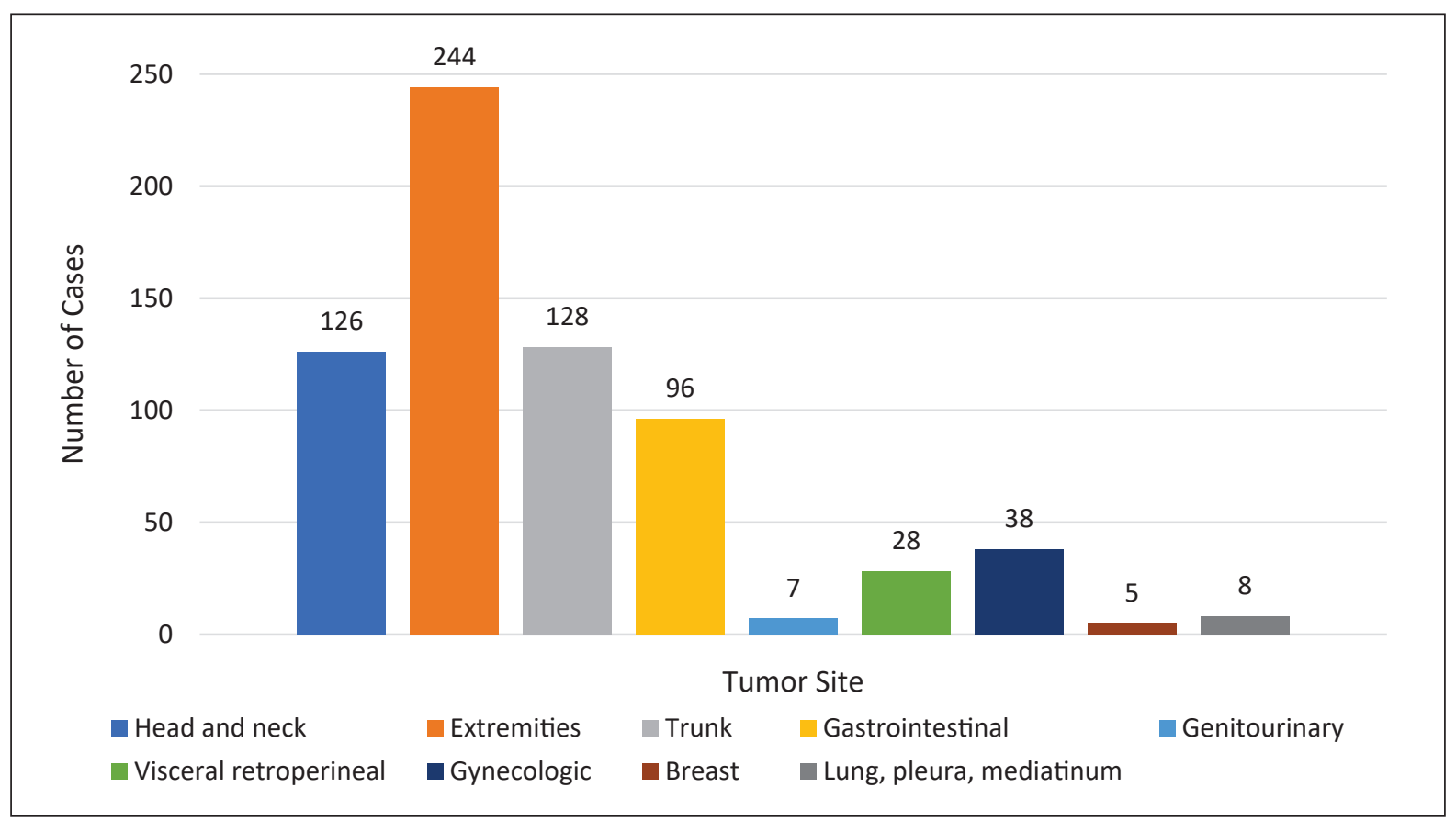

Figure 5. Distribution of STTI and STS diagnosed in PGH from January 1, 2014 to December 31, 2018 according to tumor site. 
Table 3. Distribution of STTI and STS according to tumor classification, age and sex, Philippine General Hospital, 2014-2018

\begin{tabular}{|c|c|c|c|c|c|c|c|c|c|c|c|}
\hline \multirow[b]{2}{*}{ Tumor Classification and Histologic Type } & \multirow[b]{2}{*}{ Number } & \multirow[b]{2}{*}{ Proportion $^{\mathrm{a}}$} & \multirow[b]{2}{*}{$95 \% \mathrm{Cl}^{\mathrm{c}}$} & \multirow[b]{2}{*}{$\begin{array}{c}\text { Median } \\
\text { age }^{c} \\
\text { (years) }\end{array}$} & \multicolumn{5}{|c|}{ Age Group, $n$} & \multicolumn{2}{|c|}{ Sex, $n$} \\
\hline & & & & & $\begin{array}{l}\text { Pediatric } \\
<18 \text { years }\end{array}$ & $\begin{array}{l}\text { Young } \\
\text { adult } \\
18-24 \\
\text { years }\end{array}$ & $\begin{array}{l}\text { Middle- } \\
\text { aged } \\
\text { Adult } 25- \\
44 \text { years }\end{array}$ & $\begin{array}{l}\text { Older } \\
\text { Adult } \\
45-64 \\
\text { years }\end{array}$ & $\begin{array}{c}\text { Elderly } \\
\geq 65 \\
\text { years }\end{array}$ & Male & Female \\
\hline Adipocytic & 70 & $10.3 \%$ & $8.01 \%, 12.58 \%$ & 56 & 0 & 0 & 18 & 35 & 17 & 40 & 30 \\
\hline Atypical lipomatous tumor & 16 & $2.4 \%$ & $1.21 \%, 3.49 \%$ & 51.5 & 0 & 0 & 4 & 10 & 2 & 11 & 5 \\
\hline Liposarcoma, well-differentiated, NOS & 16 & $2.4 \%$ & $1.21 \%, 3.49 \%$ & 58 & 0 & 0 & 3 & 8 & 5 & 9 & 7 \\
\hline Lipoma-like liposarcoma & 0 & $0.0 \%$ & NA & NA & 0 & 0 & 0 & 0 & 0 & 0 & 0 \\
\hline Inflammatory liposarcoma & 0 & $0.0 \%$ & NA & NA & 0 & 0 & 0 & 0 & 0 & 0 & 0 \\
\hline Sclerosing liposarcoma & 0 & $0.0 \%$ & NA & NA & 0 & 0 & 0 & 0 & 0 & 0 & 0 \\
\hline Dedifferentiated liposarcoma & 7 & $1.0 \%$ & $0.27 \%, 1.79 \%$ & 62 & 0 & 0 & 2 & 2 & 3 & 4 & 3 \\
\hline Myxoid liposarcoma & 22 & $3.2 \%$ & $1.91 \%, 4.57 \%$ & 55.5 & 0 & 0 & 8 & 9 & 5 & 11 & 11 \\
\hline Pleomorphic liposarcoma & 8 & $1.2 \%$ & $0.37 \%, 1.99 \%$ & 59 & 0 & 0 & 0 & 6 & 2 & 5 & 3 \\
\hline Epithelioid liposarcoma & 1 & $0.1 \%$ & $0.01 \%, 0.44 \%$ & NA & 0 & 0 & 1 & 0 & 0 & 0 & 1 \\
\hline Myxoid pleomorphic liposarcoma & 0 & $0.0 \%$ & NA & NA & 0 & 0 & 0 & 0 & 0 & 0 & 0 \\
\hline Fibroblastic/Myofibroblastic & 100 & $14.7 \%$ & $12.04,17.37$ & 38 & 20 & 12 & 38 & 26 & 4 & 33 & 67 \\
\hline Fibromatosis $^{\mathrm{b}}$ & 22 & $3.2 \%$ & $1.91 \%, 4.57 \%$ & 26 & 9 & 1 & 8 & 4 & 0 & 7 & 15 \\
\hline Solitary fibrous tumor, benign & 0 & $0.0 \%$ & NA & NA & 0 & 0 & 0 & 0 & 0 & 0 & 0 \\
\hline Palmar/plantar-type fibromatosis & 0 & $0.0 \%$ & NA & NA & 0 & 0 & 0 & 0 & 0 & 0 & 0 \\
\hline Desmoid-type fibromatosis & 4 & $0.6 \%$ & $0.01 \%, 1.16 \%$ & 31.5 & 2 & 0 & 2 & 0 & 0 & 2 & 2 \\
\hline Extra-abdominal desmoid & 1 & $0.1 \%$ & $0.01 \%, 0.44 \%$ & NA & 1 & 0 & 0 & 0 & 0 & 0 & 1 \\
\hline Abdominal fibromatosis & 1 & $0.1 \%$ & $0.01 \%, 0.44 \%$ & NA & 0 & 0 & 0 & 1 & 0 & 1 & 0 \\
\hline Lipofibromatosis & 0 & $0.0 \%$ & NA & NA & 0 & 0 & 0 & 0 & 0 & 0 & 0 \\
\hline Giant cell fibroblastoma & 0 & $0.0 \%$ & NA & NA & 0 & 0 & 0 & 0 & 0 & 0 & 0 \\
\hline Dermatofibrosarcoma protuberans NOS & 20 & $2.9 \%$ & $1.67 \%, 4.21 \%$ & 41 & 0 & 3 & 12 & 5 & 0 & 8 & 12 \\
\hline Pigmented dermatofibrosarcoma protuberans & 0 & $0.0 \%$ & NA & NA & 0 & 0 & 0 & 0 & 0 & 0 & 0 \\
\hline Dermatofibrosarcoma protuberans, fibrosarcomatous & 1 & $0.1 \%$ & $0.01 \%, 0.44 \%$ & NA & 0 & 0 & 0 & 0 & 1 & 0 & 1 \\
\hline Myxoid dermatofibrosarcoma protuberans & 2 & $0.3 \%$ & $0.01 \%, 0.70 \%$ & NA & 0 & 0 & 0 & 2 & 0 & 1 & 1 \\
\hline $\begin{array}{l}\text { Dermatofibrosarcoma protuberans with myoid } \\
\text { differentiation }\end{array}$ & 0 & $0.0 \%$ & NA & NA & 0 & 0 & 0 & 0 & 0 & 0 & 0 \\
\hline Plaque-like dermatofibrosarcoma protuberans & 0 & $0.0 \%$ & NA & NA & 0 & 0 & 0 & 0 & 0 & 0 & 0 \\
\hline Solitary fibrous tumor NOS & 25 & $3.7 \%$ & $2.26 \%, 5.09 \%$ & 44 & 4 & 4 & 10 & 7 & 0 & 8 & 17 \\
\hline Fat-forming (lipomatous) solitary fibrous tumour & 0 & $0.0 \%$ & NA & NA & 0 & 0 & 0 & 0 & 0 & 0 & 0 \\
\hline Giant cell-rich solitary fibrous tumour & 0 & $0.0 \%$ & NA & NA & 0 & 0 & 0 & 0 & 0 & 0 & 0 \\
\hline Inflammatory myofibroblastic tumour & 7 & $1.0 \%$ & $0.27 \%, 1.79 \%$ & 18 & 3 & 1 & 0 & 3 & 0 & 2 & 5 \\
\hline Epithelioid inflammatory myofibroblastic sarcoma & 0 & $0.0 \%$ & NA & NA & 0 & 0 & 0 & 0 & 0 & 0 & 0 \\
\hline Myofibroblastic sarcoma & 6 & $0.9 \%$ & $0.18 \%, 1.59 \%$ & 26 & 0 & 3 & 1 & 2 & 0 & 0 & 6 \\
\hline Superficial CD34-positive fibroblastic tumor & 0 & $0.0 \%$ & NA & NA & 0 & 0 & 0 & 0 & 0 & 0 & 0 \\
\hline Myxoinflammatory fibroblastic sarcoma & 0 & $0.0 \%$ & NA & NA & 0 & 0 & 0 & 0 & 0 & 0 & 0 \\
\hline Infantile fibrosarcoma & 0 & $0.0 \%$ & NA & NA & 0 & 0 & 0 & 0 & 0 & 0 & 0 \\
\hline Solitary fibrous tumor, malignant & 2 & $0.3 \%$ & $0.01 \%, 0.70 \%$ & NA & 0 & 0 & 1 & 1 & 0 & 1 & 1 \\
\hline Fibrosarcoma NOS & 4 & $0.6 \%$ & $0.01 \%, 1.16 \%$ & 37.5 & 1 & 0 & 3 & 0 & 0 & 1 & 3 \\
\hline Myxofibrosarcoma & 3 & $0.4 \%$ & $0.01 \%, 0.94 \%$ & 65 & 0 & 0 & 0 & 1 & 2 & 0 & 3 \\
\hline Epithelioid myxofibrosarcoma & 0 & $0.0 \%$ & NA & NA & 0 & 0 & 0 & 0 & 0 & 0 & 0 \\
\hline Low-grade fibromyxoid sarcoma & 1 & $0.1 \%$ & $0.01 \%, 0.44 \%$ & NA & 0 & 0 & 1 & 0 & 0 & 1 & 0 \\
\hline Sclerosing epithelioid fibrosarcoma & 1 & $0.1 \%$ & $0.01 \%, 0.44 \%$ & NA & 0 & 0 & 0 & 0 & 1 & 1 & 0 \\
\hline Fibrohistiocytic & 1 & $0.1 \%$ & $0.01-0.44$ & NA & 0 & 0 & 0 & 1 & 0 & 1 & 0 \\
\hline Plexiform fibrohistiocytic tumor & 0 & $0.0 \%$ & NA & NA & 0 & 0 & 0 & 0 & 0 & 0 & 0 \\
\hline Giant cell tumour of soft parts NOS & 1 & $0.1 \%$ & $0.01 \%, 0.44 \%$ & NA & 0 & 0 & 0 & 1 & 0 & 1 & 0 \\
\hline Malignant tenosynovial giant cell tumour & 0 & $0.0 \%$ & NA & NA & 0 & 0 & 0 & 0 & 0 & 0 & 0 \\
\hline $\begin{array}{l}\text { Smooth muscle } \\
\end{array}$ & 68 & $10.0 \%$ & $7.75,12.25$ & 53.5 & 0 & 2 & 17 & 39 & 10 & 14 & 54 \\
\hline Smooth muscle tumour of uncertain malignant potential & 6 & $0.9 \%$ & $0.18 \%, 1.59 \%$ & 45.5 & 0 & 1 & 2 & 3 & 0 & 0 & 6 \\
\hline Leiomyosarcoma NOS & 62 & $9.1 \%$ & $6.95 \%, 11.28 \%$ & 54 & 0 & 1 & 15 & 36 & 10 & 14 & 48 \\
\hline Skeletal muscle & 31 & $4.6 \%$ & $2.99,6.13$ & 10 & 22 & 5 & 1 & 3 & 0 & 15 & 16 \\
\hline Rhabdomyosarcoma $^{\mathrm{b}}$ & 12 & $1.8 \%$ & $0.78 \%, 2.75 \%$ & 12.5 & 7 & 3 & 0 & 2 & 0 & 5 & 7 \\
\hline Rhabdomyosarcoma, "Embryonal-Alveolar"b & 1 & $0.1 \%$ & $0.01 \%, 0.44 \%$ & NA & 1 & 0 & 0 & 0 & 0 & 1 & 0 \\
\hline Embryonal rhabdomyosarcoma NOS & 11 & $1.6 \%$ & $0.67 \%, 2.57 \%$ & 10 & 10 & 1 & 0 & 0 & 0 & 5 & 6 \\
\hline Embryonal rhabdomyosarcoma, pleomorphic & 0 & $0.0 \%$ & NA & NA & 0 & 0 & 0 & 0 & 0 & 0 & 0 \\
\hline Alveolar rhabdomyosarcoma & 5 & $0.7 \%$ & $0.09 \%, 1.38 \%$ & 14 & 3 & 1 & 0 & 1 & 0 & 3 & 2 \\
\hline Pleomorphic rhabdomyosarcoma NOS & 1 & $0.1 \%$ & $0.01 \%, 0.44 \%$ & NA & 0 & 0 & 1 & 0 & 0 & 1 & 0 \\
\hline Spindle cell rhabdomyosarcoma & 1 & $0.1 \%$ & $0.01 \%, 0.44 \%$ & NA & 1 & 0 & 0 & 0 & 0 & 0 & 1 \\
\hline $\begin{array}{l}\text { Congenital spindle cell rhabdomyosarcoma with } \\
\text { VGLL2/NCOA2/CITED2 rearrangements }\end{array}$ & 0 & $0.0 \%$ & NA & NA & 0 & 0 & 0 & 0 & 0 & 0 & 0 \\
\hline $\begin{array}{l}\text { MYOD1-mutant spindle cell/sclerosing } \\
\text { rhabdomyosarcoma }\end{array}$ & 0 & $0.0 \%$ & NA & NA & 0 & 0 & 0 & 0 & 0 & 0 & 0 \\
\hline $\begin{array}{l}\text { Intraosseous spindle cell rhabdomyosarcoma (with } \\
\text { TFCP2/NCOA2 rearrangements) }\end{array}$ & 0 & $0.0 \%$ & NA & NA & 0 & 0 & 0 & 0 & 0 & 0 & 0 \\
\hline Ectomesenchymoma & 0 & $0.0 \%$ & NA & NA & 0 & 0 & 0 & 0 & 0 & 0 & 0 \\
\hline
\end{tabular}


Table 3. Distribution of STTI and STS according to tumor classification, age and sex, Philippine General Hospital, 2014-2018 (continued)

\begin{tabular}{|c|c|c|c|c|c|c|c|c|c|c|c|}
\hline \multirow[b]{2}{*}{ Tumor Classification and Histologic Type } & \multirow[b]{2}{*}{ Number } & \multirow[b]{2}{*}{ Proportion $^{\mathrm{a}}$} & \multirow[b]{2}{*}{$95 \% \mathrm{Cl}^{\mathrm{c}}$} & \multirow[b]{2}{*}{$\begin{array}{c}\text { Median } \\
\text { age }^{c} \\
\text { (years) }\end{array}$} & \multicolumn{5}{|c|}{ Age Group, $n$} & \multicolumn{2}{|c|}{ Sex, $n$} \\
\hline & & & & & $\begin{array}{l}\text { Pediatric } \\
<18 \text { years }\end{array}$ & $\begin{array}{l}\text { Young } \\
\text { adult } \\
18-24 \\
\text { years }\end{array}$ & $\begin{array}{l}\text { Middle- } \\
\text { aged } \\
\text { Adult 25- } \\
44 \text { years }\end{array}$ & $\begin{array}{l}\text { Older } \\
\text { Adult } \\
45-64 \\
\text { years }\end{array}$ & $\begin{array}{c}\text { Elderly } \\
\geq 65 \\
\text { years }\end{array}$ & Male & Female \\
\hline Vascular & 18 & $2.6 \%$ & $1.44,3.85$ & 30.5 & 1 & 2 & 9 & 4 & 2 & 11 & 7 \\
\hline Hemangioendothelioma $^{\mathrm{b}}$ & 3 & $0.4 \%$ & $0.01 \%, 0.94 \%$ & 49 & 0 & 0 & 1 & 1 & 1 & 1 & 2 \\
\hline Kaposiform hemangioendothelioma & 1 & $0.1 \%$ & $0.01 \%, 0.44 \%$ & NA & 0 & 1 & 0 & 0 & 0 & 0 & 1 \\
\hline Retiform haemangioendothelioma & 0 & $0.0 \%$ & NA & NA & 0 & 0 & 0 & 0 & 0 & 0 & 0 \\
\hline Papillary intralymphatic angioendothelioma & 0 & $0.0 \%$ & NA & NA & 0 & 0 & 0 & 0 & 0 & 0 & 0 \\
\hline Composite haemangioendothelioma & 0 & $0.0 \%$ & NA & NA & 0 & 0 & 0 & 0 & 0 & 0 & 0 \\
\hline Neuroendocrine composite haemangioendothelioma & 0 & $0.0 \%$ & NA & NA & 0 & 0 & 0 & 0 & 0 & 0 & 0 \\
\hline Kaposi sarcoma & 2 & $0.3 \%$ & $0.01 \%, 0.70 \%$ & NA & 0 & 0 & 2 & 0 & 0 & 2 & 0 \\
\hline Classic indolent Kaposi sarcoma & 0 & $0.0 \%$ & NA & NA & 0 & 0 & 0 & 0 & 0 & 0 & 0 \\
\hline Endemic African Kaposi sarcoma & 0 & $0.0 \%$ & NA & NA & 0 & 0 & 0 & 0 & 0 & 0 & 0 \\
\hline AIDS-associated Kaposi sarcoma & 0 & $0.0 \%$ & NA & NA & 0 & 0 & 0 & 0 & 0 & 0 & 0 \\
\hline latrogenic Kaposi sarcoma & 0 & $0.0 \%$ & NA & NA & 0 & 0 & 0 & 0 & 0 & 0 & 0 \\
\hline $\begin{array}{l}\text { Pseudomyogenic (epithelioid sarcoma-like) } \\
\text { haemangioendothelioma }\end{array}$ & 0 & $0.0 \%$ & NA & NA & 0 & 0 & 0 & 0 & 0 & 0 & 0 \\
\hline Epithelioid haemangioendothelioma NOS & 3 & $0.4 \%$ & $0.01 \%, 0.94 \%$ & 64 & 0 & 0 & 1 & 1 & 1 & 3 & 0 \\
\hline $\begin{array}{l}\text { Epithelioid haemangioendothelioma with WWTR1- } \\
\text { CAMTA1 fusion }\end{array}$ & 0 & $0.0 \%$ & NA & NA & 0 & 0 & 0 & 0 & 0 & 0 & 0 \\
\hline $\begin{array}{l}\text { Epithelioid haemangioendothelioma with YAP1- } \\
\text { TFE3 fusion }\end{array}$ & 0 & $0.0 \%$ & NA & NA & 0 & 0 & 0 & 0 & 0 & 0 & 0 \\
\hline Angiosarcoma & 9 & $1.3 \%$ & $0.46 \%, 2.18 \%$ & 30 & 1 & 1 & 5 & 2 & 0 & 5 & 4 \\
\hline Tumors of peripheral nerves & 54 & $7.9 \%$ & $5.91,9.97$ & 33 & 7 & 8 & 16 & 13 & 10 & 26 & 28 \\
\hline Malignant peripheral nerve sheath tumour NOS & 54 & $7.9 \%$ & $5.91 \%, 9.97 \%$ & 33 & 7 & 8 & 16 & 13 & 10 & 26 & 28 \\
\hline Malignant peripheral nerve sheath tumour, epithelioid & 0 & $0.0 \%$ & NA & NA & 0 & 0 & 0 & 0 & 0 & 0 & 0 \\
\hline Melanotic malignant peripheral nerve sheath tumour & 0 & $0.0 \%$ & NA & NA & 0 & 0 & 0 & 0 & 0 & 0 & 0 \\
\hline Granular cell tumour, malignant & 0 & $0.0 \%$ & NA & NA & 0 & 0 & 0 & 0 & 0 & 0 & 0 \\
\hline Perineurioma, malignant & 0 & $0.0 \%$ & NA & NA & 0 & 0 & 0 & 0 & 0 & 0 & 0 \\
\hline Chondro-osseous & 3 & $0.4 \%$ & $0.01,0.94$ & 59 & 0 & 0 & 1 & 1 & 1 & 3 & 0 \\
\hline Osteosarcoma, extraskeletal & 3 & $0.4 \%$ & $0.01,0.94$ & 59 & 0 & 0 & 1 & 1 & 1 & 3 & 0 \\
\hline Gastrointestinal stromal tumors & 91 & $13.4 \%$ & $10.82,15.94$ & 62 & 0 & 0 & 9 & 44 & 38 & 41 & 50 \\
\hline Gastrointestinal stromal tumor & 91 & $13.4 \%$ & $10.82,15.94$ & 62 & 0 & 0 & 9 & 44 & 38 & 41 & 50 \\
\hline Tumors of uncertain differentiation & 61 & $9.0 \%$ & $6.82,11.12$ & 36 & 7 & 12 & 23 & 13 & 6 & 30 & 31 \\
\hline Haemosiderotic fibrolipomatous tumor & 0 & $0.0 \%$ & NA & NA & 0 & 0 & 0 & 0 & 0 & 0 & 0 \\
\hline Angiomyolipoma, epithelioid & 0 & $0.0 \%$ & NA & NA & 0 & 0 & 0 & 0 & 0 & 0 & 0 \\
\hline Atypical fibroxanthoma & 0 & $0.0 \%$ & NA & NA & 0 & 0 & 0 & 0 & 0 & 0 & 0 \\
\hline Angiomatoid fibrous histiocytoma & 0 & $0.0 \%$ & NA & NA & 0 & 0 & 0 & 0 & 0 & 0 & 0 \\
\hline Ossifying fibromyxoid tumour NOS & 0 & $0.0 \%$ & NA & NA & 0 & 0 & 0 & 0 & 0 & 0 & 0 \\
\hline Mixed tumour NOS & 0 & $0.0 \%$ & NA & NA & 0 & 0 & 0 & 0 & 0 & 0 & 0 \\
\hline Mixed tumour, malignant, NOS & 0 & $0.0 \%$ & NA & NA & 0 & 0 & 0 & 0 & 0 & 0 & 0 \\
\hline Myoepithelioma NOS & 0 & $0.0 \%$ & NA & NA & 0 & 0 & 0 & 0 & 0 & 0 & 0 \\
\hline Phosphaturic mesenchymal tumour, malignant & 0 & $0.0 \%$ & NA & NA & 0 & 0 & 0 & 0 & 0 & 0 & 0 \\
\hline NTRK-rearranged spindle cell neoplasm (emerging) & 0 & $0.0 \%$ & NA & NA & 0 & 0 & 0 & 0 & 0 & 0 & 0 \\
\hline Synovial sarcoma NOS & 31 & $4.6 \%$ & $2.99 \%, 6.13 \%$ & 29 & 5 & 8 & 13 & 3 & 2 & 12 & 19 \\
\hline Synovial sarcoma, spindle cell & 0 & $0.0 \%$ & NA & NA & 0 & 0 & 0 & 0 & 0 & 0 & 0 \\
\hline Synovial sarcoma, biphasic & 6 & $0.9 \%$ & $0.18 \%, 1.59 \%$ & 37 & 0 & 2 & 3 & 1 & 0 & 4 & 2 \\
\hline Synovial sarcoma, poorly differentiated & 0 & $0.0 \%$ & NA & NA & 0 & 0 & 0 & 0 & 0 & 0 & 0 \\
\hline Epithelioid sarcoma & 1 & $0.1 \%$ & $0.01 \%, 0.44 \%$ & NA & 0 & 0 & 0 & 1 & 0 & 0 & 1 \\
\hline Proximal or large cell epithelioid sarcoma & 0 & $0.0 \%$ & NA & NA & 0 & 0 & 0 & 0 & 0 & 0 & 0 \\
\hline Classic epithelioid sarcoma & 0 & $0.0 \%$ & NA & NA & 0 & 0 & 0 & 0 & 0 & 0 & 0 \\
\hline Alveolar soft part sarcoma & 3 & $0.4 \%$ & $0.01 \%, 0.94 \%$ & 28 & 1 & 0 & 2 & 0 & 0 & 2 & 1 \\
\hline Clear cell sarcoma NOS & 1 & $0.1 \%$ & $0.01 \%, 0.44 \%$ & NA & 0 & 0 & 1 & 0 & 0 & 1 & 0 \\
\hline Extraskeletal myxoid chondrosarcoma & 0 & $0.0 \%$ & NA & NA & 0 & 0 & 0 & 0 & 0 & 0 & 0 \\
\hline Desmoplastic small round cell tumour & 1 & $0.1 \%$ & $0.01 \%, 0.44 \%$ & NA & 1 & 0 & 0 & 0 & 0 & 1 & 0 \\
\hline Rhabdoid tumour NOS & 1 & $0.1 \%$ & $0.01 \%, 0.44 \%$ & NA & 0 & 1 & 0 & 0 & 0 & 0 & 1 \\
\hline Perivascular epithelioid tumour, malignant & 0 & $0.0 \%$ & NA & NA & 0 & 0 & 0 & 0 & 0 & 0 & 0 \\
\hline Intimal sarcoma & 0 & $0.0 \%$ & NA & NA & 0 & 0 & 0 & 0 & 0 & 0 & 0 \\
\hline Ossifying fibromyxoid tumour, malignant & 0 & $0.0 \%$ & NA & NA & 0 & 0 & 0 & 0 & 0 & 0 & 0 \\
\hline Myoepithelial carcinoma & 0 & $0.0 \%$ & NA & NA & 0 & 0 & 0 & 0 & 0 & 0 & 0 \\
\hline Undifferentiated sarcoma & 3 & $0.4 \%$ & $0.01 \%, 0.94 \%$ & 60 & 0 & 0 & 1 & 1 & 1 & 1 & 2 \\
\hline Spindle cell sarcoma, undifferentiated & 0 & $0.0 \%$ & NA & NA & 0 & 0 & 0 & 0 & 0 & 0 & 0 \\
\hline Pleomorphic sarcoma, undifferentiated & 14 & $2.1 \%$ & $0.99 \%, 3.13 \%$ & 58 & 0 & 1 & 3 & 7 & 3 & 9 & 5 \\
\hline Round cell sarcoma, undifferentiated & 0 & $0.0 \%$ & NA & NA & 0 & 0 & 0 & 0 & 0 & 0 & 0 \\
\hline $\begin{array}{c}\text { Undifferentiated small round cell sarcomas } \\
\text { of bone and soft tissue }\end{array}$ & 34 & $5.0 \%$ & $3.36,6.64$ & 15.5 & 24 & 3 & 5 & 2 & 0 & 22 & 12 \\
\hline Ewing sarcoma & 32 & $4.7 \%$ & $3.11 \%, 6.30 \%$ & 15.5 & 23 & 2 & 5 & 2 & 0 & 22 & 10 \\
\hline Round cell sarcoma with EWSR1-non-ETS fusions & 0 & $0.0 \%$ & NA & NA & 0 & 0 & 0 & 0 & 0 & 0 & 0 \\
\hline C/C-rearranged sarcoma & 2 & $0.3 \%$ & $0.01 \%, 0.70 \%$ & NA & 1 & 1 & 0 & 0 & 0 & 0 & 2 \\
\hline Sarcoma with $B C O R$ genetic alterations & 0 & $0.0 \%$ & NA & NA & 0 & 0 & 0 & 0 & 0 & 0 & 0 \\
\hline Sarcoma, NOS & 149 & $21.9 \%$ & 18.80.25.02 & 50 & 9 & 17 & 38 & 59 & 26 & 73 & 76 \\
\hline Total & 680 & $100 \%$ & & $47^{\mathrm{d}}$ & 90 & 61 & 175 & 240 & 114 & 309 & 371 \\
\hline
\end{tabular}


Table 4. Distribution of STTI and STS according to tumor site, Philippine General Hospital, 2014-2018

\begin{tabular}{|c|c|c|c|c|c|c|c|c|c|c|}
\hline \multirow[b]{2}{*}{ Tumor Classification and Histologic Type } & \multicolumn{9}{|c|}{ Tumor Site, $n$} & \multirow[b]{2}{*}{ Total } \\
\hline & $\begin{array}{l}\text { Head } \\
\text { and } \\
\text { neck }\end{array}$ & $\begin{array}{l}\text { Extremi- } \\
\text { ties }\end{array}$ & Trunk & $\begin{array}{l}\text { Gastro- } \\
\text { intestinal }\end{array}$ & $\begin{array}{l}\text { Genito- } \\
\text { urinary }\end{array}$ & $\begin{array}{l}\text { Visceral } \\
\text { retroperi- } \\
\text { toneal }\end{array}$ & $\begin{array}{l}\text { Gyneco- } \\
\text { logic }\end{array}$ & Breast & $\begin{array}{l}\text { Lung, pleura, } \\
\text { mediastinum }\end{array}$ & \\
\hline Adipocytic & 4 & 33 & 19 & 4 & 0 & 8 & 0 & 0 & 2 & 70 \\
\hline Atypical lipomatous tumor & 1 & 10 & 5 & 0 & 0 & 0 & 0 & 0 & 0 & 16 \\
\hline Liposarcoma, well-differentiated, NOS & 1 & 7 & 2 & 2 & 0 & 4 & 0 & 0 & 0 & 16 \\
\hline Lipoma-like liposarcoma & 0 & 0 & 0 & 0 & 0 & 0 & 0 & 0 & 0 & 0 \\
\hline Inflammatory liposarcoma & 0 & 0 & 0 & 0 & 0 & 0 & 0 & 0 & 0 & 0 \\
\hline Sclerosing liposarcoma & 0 & 0 & 0 & 0 & 0 & 0 & 0 & 0 & 0 & 0 \\
\hline Dedifferentiated liposarcoma & 1 & 2 & 3 & 0 & 0 & 1 & 0 & 0 & 0 & 7 \\
\hline Myxoid liposarcoma & 1 & 8 & 6 & 2 & 0 & 3 & 0 & 0 & 2 & 22 \\
\hline Pleomorphic liposarcoma & 0 & 5 & 3 & 0 & 0 & 0 & 0 & 0 & 0 & 8 \\
\hline Epithelioid liposarcoma & 0 & 1 & 0 & 0 & 0 & 0 & 0 & 0 & 0 & 1 \\
\hline Myxoid pleomorphic liposarcoma & 0 & 0 & 0 & 0 & 0 & 0 & 0 & 0 & 0 & 0 \\
\hline Fibroblastic/Myofibroblastic & 35 & 26 & 31 & 3 & 0 & 2 & 0 & 1 & 2 & 100 \\
\hline Fibromatosis & 7 & 10 & 4 & 0 & 0 & 0 & 0 & 0 & 1 & 22 \\
\hline Solitary fibrous tumor, benign & 0 & 0 & 0 & 0 & 0 & 0 & 0 & 0 & 0 & 0 \\
\hline Palmar/plantar-type fibromatosis & 0 & 0 & 0 & 0 & 0 & 0 & 0 & 0 & 0 & 0 \\
\hline Desmoid-type fibromatosis & 1 & 0 & 3 & 0 & 0 & 0 & 0 & 0 & 0 & 4 \\
\hline Extra-abdominal desmoid & 0 & 1 & 0 & 0 & 0 & 0 & 0 & 0 & 0 & 1 \\
\hline Abdominal fibromatosis & 0 & 0 & 0 & 1 & 0 & 0 & 0 & 0 & 0 & 1 \\
\hline Lipofibromatosis & 0 & 0 & 0 & 0 & 0 & 0 & 0 & 0 & 0 & 0 \\
\hline Giant cell fibroblastoma & 0 & 0 & 0 & 0 & 0 & 0 & 0 & 0 & 0 & 0 \\
\hline Dermatofibrosarcoma protuberans NOS & 3 & 5 & 11 & 0 & 0 & 0 & 0 & 1 & 0 & 20 \\
\hline Pigmented dermatofibrosarcoma protuberans & 0 & 0 & 0 & 0 & 0 & 0 & 0 & 0 & 0 & 0 \\
\hline Dermatofibrosarcoma protuberans, fibrosarcomatous & 0 & 0 & 1 & 0 & 0 & 0 & 0 & 0 & 0 & 1 \\
\hline Myxoid dermatofibrosarcoma protuberans & 1 & 0 & 1 & 0 & 0 & 0 & 0 & 0 & 0 & 2 \\
\hline Dermatofibrosarcoma protuberanswith myoid differentiation & 0 & 0 & 0 & 0 & 0 & 0 & 0 & 0 & 0 & 0 \\
\hline Plaque-like dermatofibrosarcoma protuberans & 0 & 0 & 0 & 0 & 0 & 0 & 0 & 0 & 0 & 0 \\
\hline Solitary fibrous tumor NOS & 14 & 5 & 5 & 0 & 0 & 1 & 0 & 0 & 0 & 25 \\
\hline Fat-forming (lipomatous) solitary fibrous tumour & 0 & 0 & 0 & 0 & 0 & 0 & 0 & 0 & 0 & 0 \\
\hline Giant cell-rich solitary fibrous tumour & 0 & 0 & 0 & 0 & 0 & 0 & 0 & 0 & 0 & 0 \\
\hline Inflammatory myofibroblastic tumour & 2 & 0 & 2 & 2 & 0 & 0 & 0 & 0 & 1 & 7 \\
\hline Epithelioid inflammatory myofibroblastic sarcoma & 0 & 0 & 0 & 0 & 0 & 0 & 0 & 0 & 0 & 0 \\
\hline Myofibroblastic sarcoma & 3 & 1 & 2 & 0 & 0 & 0 & 0 & 0 & 0 & 6 \\
\hline Superficial CD34-positive fibroblastic tumor & 0 & 0 & 0 & 0 & 0 & 0 & 0 & 0 & 0 & 0 \\
\hline Myxoinflammatory fibroblastic sarcoma & 0 & 0 & 0 & 0 & 0 & 0 & 0 & 0 & 0 & 0 \\
\hline Infantile fibrosarcoma & 0 & 0 & 0 & 0 & 0 & 0 & 0 & 0 & 0 & 0 \\
\hline Solitary fibrous tumor, malignant & 1 & 0 & 0 & 0 & 0 & 1 & 0 & 0 & 0 & 2 \\
\hline Fibrosarcoma NOS & 2 & 1 & 1 & 0 & 0 & 0 & 0 & 0 & 0 & 4 \\
\hline Myxofibrosarcoma & 0 & 2 & 1 & 0 & 0 & 0 & 0 & 0 & 0 & 3 \\
\hline Epithelioid myxofibrosarcoma & 0 & 0 & 0 & 0 & 0 & 0 & 0 & 0 & 0 & 0 \\
\hline Low-grade fibromyxoid sarcoma & 1 & 0 & 0 & 0 & 0 & 0 & 0 & 0 & 0 & 1 \\
\hline Sclerosing epithelioid fibrosarcoma & 0 & 1 & 0 & 0 & 0 & 0 & 0 & 0 & 0 & 1 \\
\hline $\begin{array}{ll} & \text { Fibrohistiocytic } \\
\end{array}$ & 0 & 0 & 1 & 0 & 0 & 0 & 0 & 0 & 0 & 1 \\
\hline Plexiform fibrohistiocytic tumor & 0 & 0 & 0 & 0 & 0 & 0 & 0 & 0 & 0 & 0 \\
\hline Giant cell tumour of soft parts NOS & 0 & 0 & 1 & 0 & 0 & 0 & 0 & 0 & 0 & 1 \\
\hline Malignant tenosynovial giant cell tumour & 0 & 0 & 0 & 0 & 0 & 0 & 0 & 0 & 0 & 0 \\
\hline Smooth muscle & 6 & 10 & 8 & 6 & 0 & 5 & 32 & 1 & 0 & 68 \\
\hline Smooth muscle tumour of uncertain malignant potential & 0 & 0 & 0 & 0 & 0 & 0 & 6 & 0 & 0 & 6 \\
\hline Leiomyosarcoma NOS & 6 & 10 & 8 & 6 & 0 & 5 & 26 & 1 & 0 & 62 \\
\hline Skeletal muscle & 19 & 6 & 3 & 0 & 2 & 1 & 0 & 0 & 0 & 31 \\
\hline Rhabdomyosarcoma & 5 & 3 & 2 & 0 & 1 & 1 & 0 & 0 & 0 & 12 \\
\hline Rhabdomyosarcoma, "Embryonal-Alveolar" & 0 & 1 & 0 & 0 & 0 & 0 & 0 & 0 & 0 & 1 \\
\hline Embryonal rhabdomyosarcoma NOS & 9 & 0 & 1 & 0 & 1 & 0 & 0 & 0 & 0 & 11 \\
\hline Embryonal rhabdomyosarcoma, pleomorphic & 0 & 0 & 0 & 0 & 0 & 0 & 0 & 0 & 0 & 0 \\
\hline Alveolar rhabdomyosarcoma & 4 & 1 & 0 & 0 & 0 & 0 & 0 & 0 & 0 & 5 \\
\hline Pleomorphic rhabdomyosarcoma NOS & 0 & 1 & 0 & 0 & 0 & 0 & 0 & 0 & 0 & 1 \\
\hline Spindle cell rhabdomyosarcoma & 1 & 0 & 0 & 0 & 0 & 0 & 0 & 0 & 0 & 1 \\
\hline $\begin{array}{l}\text { Congenital spindle cell rhabdomyosarcoma with VGLL2/NCOA2/CITED2 } \\
\text { rearrangements }\end{array}$ & 0 & 0 & 0 & 0 & 0 & 0 & 0 & 0 & 0 & 0 \\
\hline MYOD1-mutant spindle cell/sclerosing rhabdomyosarcoma & 0 & 0 & 0 & 0 & 0 & 0 & 0 & 0 & 0 & 0 \\
\hline $\begin{array}{l}\text { Intraosseous spindle cell rhabdomyosarcoma (with TFCP2/NCOA2 } \\
\text { rearrangements) }\end{array}$ & 0 & 0 & 0 & 0 & 0 & 0 & 0 & 0 & 0 & 0 \\
\hline Ectomesenchymoma & 0 & 0 & 0 & 0 & 0 & 0 & 0 & 0 & 0 & 0 \\
\hline
\end{tabular}


Table 4. Distribution of STTI and STS according to tumor site, Philippine General Hospital, 2014-2018 (continued)

\begin{tabular}{|c|c|c|c|c|c|c|c|c|c|c|}
\hline \multirow[b]{2}{*}{ Tumor Classification and Histologic Type } & \multicolumn{9}{|c|}{ Tumor Site, $n$} & \multirow[b]{2}{*}{ Tota } \\
\hline & $\begin{array}{l}\text { Head } \\
\text { and } \\
\text { neck }\end{array}$ & $\begin{array}{l}\text { Extremi- } \\
\text { ties }\end{array}$ & Trunk & $\begin{array}{c}\text { Gastro- } \\
\text { intestinal }\end{array}$ & $\begin{array}{l}\text { Genito- } \\
\text { urinary }\end{array}$ & $\begin{array}{l}\text { Visceral } \\
\text { retroperi- } \\
\text { toneal }\end{array}$ & $\begin{array}{l}\text { Gyneco- } \\
\text { logic }\end{array}$ & Breast & $\begin{array}{l}\text { Lung, pleura, } \\
\text { mediastinum }\end{array}$ & \\
\hline Vascular & 6 & 8 & 2 & 2 & 0 & 0 & 0 & 0 & 0 & 18 \\
\hline Hemangioendothelioma & 2 & 1 & 0 & 0 & 0 & 0 & 0 & 0 & 0 & 3 \\
\hline Kaposiform hemangioendothelioma & 1 & 0 & 0 & 0 & 0 & 0 & 0 & 0 & 0 & 1 \\
\hline Retiform haemangioendothelioma & 0 & 0 & 0 & 0 & 0 & 0 & 0 & 0 & 0 & 0 \\
\hline Papillary intralymphatic angioendothelioma & 0 & 0 & 0 & 0 & 0 & 0 & 0 & 0 & 0 & 0 \\
\hline Composite haemangioendothelioma & 0 & 0 & 0 & 0 & 0 & 0 & 0 & 0 & 0 & 0 \\
\hline Neuroendocrine composite haemangioendothelioma & 0 & 0 & 0 & 0 & 0 & 0 & 0 & 0 & 0 & 0 \\
\hline Kaposi sarcoma & 1 & 0 & 0 & 1 & 0 & 0 & 0 & 0 & 0 & 2 \\
\hline Classic indolent Kaposi sarcoma & 0 & 0 & 0 & 0 & 0 & 0 & 0 & 0 & 0 & 0 \\
\hline Endemic African Kaposi sarcoma & 0 & 0 & 0 & 0 & 0 & 0 & 0 & 0 & 0 & 0 \\
\hline AIDS-associated Kaposi sarcoma & 0 & 0 & 0 & 0 & 0 & 0 & 0 & 0 & 0 & 0 \\
\hline latrogenic Kaposi sarcoma & 0 & 0 & 0 & 0 & 0 & 0 & 0 & 0 & 0 & 0 \\
\hline Pseudomyogenic (epithelioid sarcoma-like) haemangioendothelioma & 0 & 0 & 0 & 0 & 0 & 0 & 0 & 0 & 0 & 0 \\
\hline Epithelioid haemangioendothelioma NOS & 0 & 2 & 0 & 1 & 0 & 0 & 0 & 0 & 0 & 3 \\
\hline Epithelioid haemangioendothelioma with WWTR1-CAMTA1 fusion & 0 & 0 & 0 & 0 & 0 & 0 & 0 & 0 & 0 & 0 \\
\hline Epithelioid haemangioendothelioma with YAP1-TFE3 fusion & 0 & 0 & 0 & 0 & 0 & 0 & 0 & 0 & 0 & 0 \\
\hline Angiosarcoma & 2 & 5 & 2 & 0 & 0 & 0 & 0 & 0 & 0 & 9 \\
\hline Tumors of peripheral nerves & 11 & 24 & 15 & 0 & 0 & 3 & 0 & 0 & 1 & 54 \\
\hline Malignant peripheral nerve sheath tumour NOS & 11 & 24 & 15 & 0 & 0 & 3 & 0 & 0 & 1 & 54 \\
\hline Malignant peripheral nerve sheath tumour, epithelioid & 0 & 0 & 0 & 0 & 0 & 0 & 0 & 0 & 0 & 0 \\
\hline Melanotic malignant peripheral nerve sheath tumour & 0 & 0 & 0 & 0 & 0 & 0 & 0 & 0 & 0 & 0 \\
\hline Granular cell tumour, malignant & 0 & 0 & 0 & 0 & 0 & 0 & 0 & 0 & 0 & 0 \\
\hline Perineurioma, malignant & 0 & 0 & 0 & 0 & 0 & 0 & 0 & 0 & 0 & 0 \\
\hline Chondro-osseous & 2 & 1 & 0 & 0 & 0 & 0 & 0 & 0 & 0 & 3 \\
\hline Osteosarcoma, extraskeletal & 2 & 1 & 0 & 0 & 0 & 0 & 0 & 0 & 0 & 3 \\
\hline Gastrointestinal stromal tumors & 0 & 1 & 10 & 76 & 0 & 2 & 2 & 0 & 0 & 91 \\
\hline Gastrointestinal stromal tumor & 0 & 1 & 10 & 76 & 0 & 2 & 2 & 0 & 0 & 91 \\
\hline Tumors of uncertain differentiation & 15 & 34 & 8 & 1 & 0 & 1 & 1 & 1 & 0 & 61 \\
\hline Haemosiderotic fibrolipomatous tumor & 0 & 0 & 0 & 0 & 0 & 0 & 0 & 0 & 0 & 0 \\
\hline Angiomyolipoma, epithelioid & 0 & 0 & 0 & 0 & 0 & 0 & 0 & 0 & 0 & 0 \\
\hline Atypical fibroxanthoma & 0 & 0 & 0 & 0 & 0 & 0 & 0 & 0 & 0 & 0 \\
\hline Angiomatoid fibrous histiocytoma & 0 & 0 & 0 & 0 & 0 & 0 & 0 & 0 & 0 & 0 \\
\hline Ossifying fibromyxoid tumour NOS & 0 & 0 & 0 & 0 & 0 & 0 & 0 & 0 & 0 & 0 \\
\hline Mixed tumour NOS & 0 & 0 & 0 & 0 & 0 & 0 & 0 & 0 & 0 & 0 \\
\hline Mixed tumour, malignant, NOS & 0 & 0 & 0 & 0 & 0 & 0 & 0 & 0 & 0 & 0 \\
\hline Myoepithelioma NOS & 0 & 0 & 0 & 0 & 0 & 0 & 0 & 0 & 0 & 0 \\
\hline Phosphaturic mesenchymal tumour, malignant & 0 & 0 & 0 & 0 & 0 & 0 & 0 & 0 & 0 & 0 \\
\hline NTRK-rearranged spindle cell neoplasm (emerging) & 0 & 0 & 0 & 0 & 0 & 0 & 0 & 0 & 0 & 0 \\
\hline Synovial sarcoma NOS & 7 & 19 & 5 & 0 & 0 & 0 & 0 & 0 & 0 & 31 \\
\hline Synovial sarcoma, spindle cell & 0 & 0 & 0 & 0 & 0 & 0 & 0 & 0 & 0 & 0 \\
\hline Synovial sarcoma, biphasic & 3 & 2 & 1 & 0 & 0 & 0 & 0 & 0 & 0 & 6 \\
\hline Synovial sarcoma, poorly differentiated & 0 & 0 & 0 & 0 & 0 & 0 & 0 & 0 & 0 & 0 \\
\hline Epithelioid sarcoma & 0 & 1 & 0 & 0 & 0 & 0 & 0 & 0 & 0 & 1 \\
\hline Proximal or large cell epithelioid sarcoma & 0 & 0 & 0 & 0 & 0 & 0 & 0 & 0 & 0 & 0 \\
\hline Classic epithelioid sarcoma & 0 & 0 & 0 & 0 & 0 & 0 & 0 & 0 & 0 & 0 \\
\hline Alveolar soft part sarcoma & 1 & 2 & 0 & 0 & 0 & 0 & 0 & 0 & 0 & 3 \\
\hline Clear cell sarcoma NOS & 0 & 1 & 0 & 0 & 0 & 0 & 0 & 0 & 0 & 1 \\
\hline Extraskeletal myxoid chondrosarcoma & 0 & 0 & 0 & 0 & 0 & 0 & 0 & 0 & 0 & 0 \\
\hline Desmoplastic small round cell tumour & 0 & 0 & 0 & 1 & 0 & 0 & 0 & 0 & 0 & 1 \\
\hline Rhabdoid tumour NOS & 0 & 1 & 0 & 0 & 0 & 0 & 0 & 0 & 0 & 1 \\
\hline Perivascular epithelioid tumour, malignant & 0 & 0 & 0 & 0 & 0 & 0 & 0 & 0 & 0 & 0 \\
\hline Intimal sarcoma & 0 & 0 & 0 & 0 & 0 & 0 & 0 & 0 & 0 & 0 \\
\hline Ossifying fibromyxoid tumour, malignant & 0 & 0 & 0 & 0 & 0 & 0 & 0 & 0 & 0 & 0 \\
\hline Myoepithelial carcinoma & 0 & 0 & 0 & 0 & 0 & 0 & 0 & 0 & 0 & 0 \\
\hline Undifferentiated sarcoma & 0 & 1 & 0 & 0 & 0 & 0 & 1 & 1 & 0 & 3 \\
\hline Spindle cell sarcoma, undifferentiated & 0 & 0 & 0 & 0 & 0 & 0 & 0 & 0 & 0 & 0 \\
\hline Pleomorphic sarcoma, undifferentiated & 4 & 7 & 2 & 0 & 0 & 1 & 0 & 0 & 0 & 14 \\
\hline Round cell sarcoma, undifferentiated & 0 & 0 & 0 & 0 & 0 & 0 & 0 & 0 & 0 & 0 \\
\hline Undifferentiated small round cell sarcomas of bone and soft tissue & 9 & 12 & 10 & 1 & 1 & 0 & 0 & 0 & 1 & 34 \\
\hline Ewing sarcoma & 9 & 11 & 10 & 0 & 1 & 0 & 0 & 0 & 1 & 32 \\
\hline Round cell sarcoma with EWSR1-non-ETS fusions & 0 & 0 & 0 & 0 & 0 & 0 & 0 & 0 & 0 & 0 \\
\hline C/C-rearranged sarcoma & 0 & 1 & 0 & 1 & 0 & 0 & 0 & 0 & 0 & 2 \\
\hline Sarcoma with BCOR genetic alterations & 0 & 0 & 0 & 0 & 0 & 0 & 0 & 0 & 0 & 0 \\
\hline Sarcoma, NOS & 19 & 89 & 21 & 3 & 4 & 6 & 3 & 2 & 2 & 149 \\
\hline Total & 126 & 244 & 128 & 96 & 7 & 28 & 38 & 5 & 8 & 680 \\
\hline
\end{tabular}




\section{CONCLUSION}

We extensively reviewed all diagnosed, as well probable, STTI and STS in PGH, from January 1, 2014 to December 31,2018 , and made apparent the significant number of tumors that need further histopathologic evaluation for a definitive assessment. Sarcoma, NOS was the most common diagnosis rendered, followed by gastrointestinal stromal tumor and leiomyosarcoma. The median age in the study was found to be 47 years, with a slight female predominance (0.83 male to female ratio), both of which were different from published WHO data. STTI and STS were found to be most commonly located in the extremities, which is consistent with available literature.

This study addresses the lack of locoregional data pertaining to soft tissue tumors in the Philippines and Asia. The advent of improved ancillary diagnostic methods will pave the way to an improved STTI and STS database that will better reflect its true epidemiology.

\section{RECOMMENDATIONS}

The authors recommend that slide review and further immunohistochemistry and/or cytogenetic studies be performed to the excluded cases. We also recommend that additional support should be given to make ancillary tests more accessible to our patient population. Furthermore, the data is available for perusal to determine what additional ancillary tests are needed to improve our diagnostic capability as a teaching and tertiary referral hospital. A formal research may also be performed to determine the various factors involved in the nonfulfillment of recommended immunohistochemistry studies.

\section{ACKNOWLEDGMENTS}

Both authors would like to express their gratitude to the PGH, Department of Laboratories, Section of Surgical Pathology for allowing us to conduct this study.

\section{STATEMENT OF AUTHORSHIP}

Both authors certified fulfillment of ICMJE authorship criteria.

\section{AUTHOR DISCLOSURE}

Both authors declared no conflict of interest.

\section{FUNDING SOURCE}

None.

\section{REFERENCES}

1. Goldblum JR, Weiss SW, Folpe AL. Enzinger and Weiss's soft tissue tumors, 7th ed. Philadelphia: Elsevier Saunders; 2020.

2. Howlader N, Noone AM, Krapcho M, et al, eds. SEER cancer statistics review, 1975-2016. National Cancer Institute. Bethesda, MD. https://seer.cancer.gov/ csr/1975_2016/ based on November 2018 SEER data submission, posted to the SEER web site. Accessed September 1, 2020.

3. Fletcher CD, Bridge JA, Hogendoorn PC, Mertens F. WHO classification of tumours of soft tissue and bone, 4th ed. Lyon: International Agency for Research on Cancer; 2013.

4. Mastrangelo GE, Coindre JM, Ducimetière F, et al. Incidence of soft tissue sarcoma and beyond: a population-based prospective study in 3 European regions. Cancer. 2020;118(21):5339-48. PMID: 22517534. https://doi.org/10.1002/cncr.27555.

5. Laurini JA, Cooper K, Fletcher CDM, et al. Protocol for the examination of resection specimens from patients with soft tissue tumors. College of American Pathologists. 2020. https://documents.cap. org/protocols/cp-other-softtissue-resection-20-4020. pdf. Accessed September 1, 2020.

6. Ngan R, Wang E, Porter D, at al. Soft-tissue sarcomas in the Asia-Pacific Region: a systematic review. Asian Pac J Cancer Prev. 2013;14(11):6821-32. PMID: 24377612. https://doi.org/10.7314/apjcp.2013.14.11.6821.

7. Ngelangel CA, Wang EH. Cancer and the Philippine Cancer Control Program. Jpn J Clin Oncol. 2002;32 Suppl:S52-61. PMID: 11959878. https://doi.org/ $10.1093 / \mathrm{jjco} / \mathrm{hye} 126$.

8. The WHO classification of tumours editorial board, ed. WHO classification of tumours of soft tissue and bone, 5 th ed. Lyon: International Agency for Research on Cancer; 2020.

9. Gage MM, Nagarajan N, Ruck JM, et al. Sarcomas in the United States: recent trends and a call for improved staging. Oncotarget. 2019;10(25):2462-74. PMID: 31069009. PMCID: PMC6497437. https://doi. org/10.18632/oncotarget.26809.

\footnotetext{
Disclaimer: This journal is OPEN ACCESS, providing immediate access to its content on the principle that making research freely available to the public supports a greater global exchange of knowledge. As a requirement for submission to the PJP, all authors have accomplished an AUTHOR FORM, which declares that the ICMJE criteria for authorship have been met by each author listed, that the article represents original material, has not been published, accepted for publication in other journals, or concurrently submitted to other journals, and that all funding and conflicts of interest have been declared. Consent forms have been secured for the publication of information about patients or cases; otherwise, authors have declared that all means have been exhausted for securing consent.
} 


\section{APPENDICES}

\section{Appendix A. Data Collection Form}

A Five-Year Review of Soft Tissue Sarcomas in a Tertiary Hospital: University of the Philippines - Philippine General Hospital (Salise, JMM and Atun, JML)

ID Number:

Age:

Sex:

Tumor Site:

Final Histopathologic Diagnosis:

\section{Appendix B. Master Spreadsheet}

\begin{tabular}{|c|c|c|c|c|c|c|}
\hline ID Number & Date (dd/mm/year) & Age & Sex & Tumor Site & Tumor Classification & Final Histopathologic Diagnosis \\
\hline & & & & & & \\
\hline & & & & & & \\
\hline & & & & & & \\
\hline & & & & & & \\
\hline & & & & & & \\
\hline & & & & & & \\
\hline & & & & & & \\
\hline
\end{tabular}

\section{Appendix C. Diagrammatic Workflow}

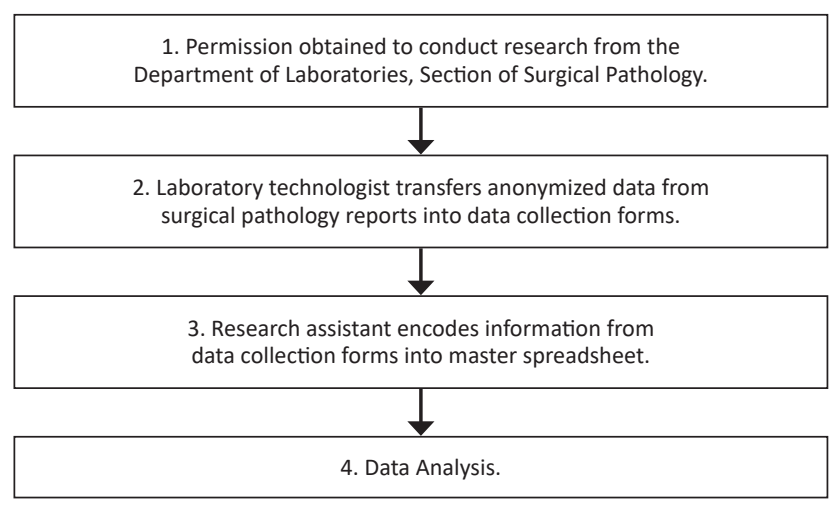

\section{Appendix D. Coding Manual}

\begin{tabular}{|c|c|c|}
\hline Variable & Type & Code \\
\hline ID Number & Field data & As is \\
\hline Age & Field data & As is \\
\hline Age group & Bracket code & $\begin{array}{l}0=\text { Pediatric (less than } 18 \text { years old }) \\
1=\text { Young Adult }(18-24 \text { years old) } \\
2=\text { Middle-aged Adult }(25-44 \text { years old }) \\
3=\text { Older Adult ( } 45-64 \text { years old) } \\
4=\text { Elderly ( } 65 \text { years old and above) }\end{array}$ \\
\hline Sex & Listing code & $\begin{array}{l}0=\text { Male } \\
1=\text { Female }\end{array}$ \\
\hline Tumor site & Listing code & $\begin{array}{l}0=\text { Head and neck } \\
1=\text { Extremities } \\
2=\text { Trunk } \\
3=\text { Gastrointestinal } \\
4=\text { Genitourinary } \\
5=\text { Visceral retroperitoneal } \\
6=\text { Gynecologic } \\
7=\text { Breast } \\
8=\text { Lung, pleura, and mediastinum } \\
9=\text { Other }\end{array}$ \\
\hline $\begin{array}{l}\text { Tumor } \\
\text { classification }\end{array}$ & Listing code & $\begin{array}{l}0=\text { Adipocytic } \\
1=\text { Fibroblastic/myofibroblastic } \\
2=\text { Fibrohistiocytic } \\
3=\text { Smooth muscle } \\
4=\text { Pericytic (perivascular) } \\
5=\text { Skeletal muscle } \\
6=\text { Vascular } \\
7=\text { Peripheral Nerve } \\
8=\text { Chondro-osseous } \\
9=\text { Gastrointestinal Stromal Tumors } \\
10=\text { Tumors of uncertain differentiation } \\
\underline{11}=\text { Undifferentiated small round cell } \\
\underline{\text { sarcomas of bone and soft tissue }} \\
12=\text { Sarcoma, NOS } \\
13=\text { Others }\end{array}$ \\
\hline $\begin{array}{l}\text { Tumor } \\
\text { histologic type }\end{array}$ & Field data & As is \\
\hline
\end{tabular}

